This Accepted Author Manuscript is copyrighted and published by Elsevier. It is posted here by agreement between Elsevier and University of Brasilia. Changes resulting from the publishing process - such as editing, corrections, structural formatting, and other quality control mechanisms - may not be reflected in this version of the text. The definitive version of the text was subsequently published in [Animal Reproduction Science, Volume 56, Issue 1, 17 May 1999, Pages 39-49, doi:10.1016/S0378-4320(99)00031-7].You may download, copy and otherwise use the AAM for non-commercial purposes provided that your license is limited by the following restrictions:

(1) You may use this AAM for non-commercial purposes only under the terms of the CC-BY-NCND license.

(2) The integrity of the work and identification of the author, copyright owner, and publisher must be preserved in any copy.

(3) You must attribute this AAM in the following format: [agreed attribution language, including link to CC BY-NC-ND license + Digital Object Identifier link to the published journal article on Elsevier's ScienceDirect ${ }^{\circledR}$ platform].

Este Manuscrito do Autor Aceito para Publicação (AAM) é protegido por direitos autorais e publicado pela Elsevier. Ele esta disponível neste Repositório, por acordo entre a Elsevier e a Universidade de Brasília. As alterações decorrentes do processo de publicação - como a edição, correção, formatação estrutural, e outros mecanismos de controle de qualidade - não estão refletidas nesta versão do texto. A versão definitiva do texto foi posteriormente publicado em [Animal Reproduction Science, Volume 56, Número 1, 17 de Maio de 1999, Páginas 39-49, doi:10.1016/S0378-4320(99)00031-7]. Você pode baixar, copiar e utilizar de outra forma o AAM para fins não comerciais, desde que sua licença seja limitada pelas seguintes restrições:

(1) Você pode usar este AAM para fins não comerciais apenas sob os termos da licença CC- BYNC-ND.

(2) A integridade do trabalho e identificação do autor, detentor dos direitos autorais e editor deve ser preservado em qualquer cópia.

(3) Tem de atribuir este AAM no seguinte formato: [acordo na linguagem atribuída, incluindo o link para CC BY-NC-ND licença Digital + DOI do artigo publicado na revista Elsevier ScienceDirect ${ }^{\circledR}$ da plataforma]. 


\title{
Effect of the interval of serial sections of ovarian tissue in the tissue chopper on the number of isolated caprine preantral follicles
}

\author{
C.M Lucci \\ C.A Amorim \\ S.N Báo \\ J.R Figueiredo \\ A.P.R Rodrigues \\ J.R.V Silva \\ P.B.D Gonçalves
}

\begin{abstract}
The present work investigated the effect of the interval of serial sections of ovarian tissue on the number of isolated preantral follicles in the goat. Goat ovaries were cut in the tissue chopper at eight different intervals. The quality of isolated follicles were evaluated by histology and transmission electron microscopy. Best results were obtained when the ovaries were cut in the tissue chopper at intervals of $75.0 \mu \mathrm{m}$ (9664 preantral follicles per ovary). Histochemical and ultrastructural analysis showed that the follicular morphology was preserved after mechanical isolation as demonstrated by the normality of oocytes and granulosa cells as well as by preservation of basement membrane. The percentages of isolated primordial, primary and secondary follicles were $96.3 \%, 2.5 \%$, and $1.2 \%$ and their average diameters were 21.5 , 34.7 and $65.3 \mu \mathrm{m}$, respectively. It was concluded that the interval of serial sections of ovarian tissue in the tissue chopper affects the number of isolated preantral follicles, and that the follicles remained intact after mechanical isolation in goats.
\end{abstract}

Keywords: Preantral follicles; Follicle quality; Follicle isolation; Goat

\section{Introduction}

Since the mammalian ovary contains many thousands of preantral follicles and most will become atretic during their growth and maturation (Carroll et al., 1990; Saumande, 1991), new investigations were focused on the in vitro culture of preantral follicles. The use of oocytes from preantral follicles for reproductive techniques could offer significant new ways for the propagation of valuable animal stocks. However, the first limiting step of this approach is the recovery of large numbers of healthy preantral follicles from the ovary.

Techniques for isolating preantral follicles from domestic species have been reported (Greenwald and Moor, 1989; Lazzari et al., 1992; Figueiredo et al., 1993; Jewgenow and Pitra, 1993; Nuttinck et al., 1993; Hulshof et al., 1994; Jewgenow and Göritz, 1995;). Figueiredo et al. (1993)showed that a large number of preantral follicles can be isolated from bovine ovaries using a tissue chopper adjusted to $50.0 \mu \mathrm{m}$ interval of serial sections. Using the same method, Rodrigues et al. (1998)described that goat preantral follicles can also be successfully isolated. However, no information about the quality of goat preantral follicles after their isolation was 
reported. Moreover, it is not known if the number of isolated goat preantral follicles can be increased by changing the interval of serial sections of ovarian tissue in the tissue chopper.

The aims of the present study were to determine the effect of the interval of serial sections of ovarian tissue in the tissue chopper on the number of isolated goat preantral follicles, and to investigate, by histological and ultrastructural analysis, the quality of the isolated preantral follicles.

\section{Material and methods}

\subsection{Ovaries}

Ovaries $(n=84)$ from adult ( $1-3$ years old) and non-pregnant mixed breed goats were collected at a local abattoir. The ovaries were washed in 70\% alcohol for, approximately, $10 \mathrm{~s}$, and twice in $0.9 \%$ saline solution. Then, each ovary was transferred into $10 \mathrm{ml}$ of saline solution and transported to the laboratory in a thermoflask filled with water at $4^{\circ} \mathrm{C}$.

\subsection{Isolation of preantral follicles}

The development of a specific mechanical method to isolate preantral ovarian follicles from adult goats was based on the mechanical procedure described by Figueiredo et al. (1993)for bovine ovaries. In the present work, eight treatments were tested which differed from each other according to the cut interval adjusted in the tissue chopper (The Mickle Laboratory Engineering, Gomshal, Surrey, UK): 12.5 (T1), 25.0 (T2), 37.5 (T3), 50.0 (T4), 62.5 (T5), 75.0 (T6), 87.5 (T7), and $100.0 \mu \mathrm{m}$ (T8). To test simultaneously all the treatments, for each replica, 12 ovaries from six goats were divided into four parts each, resulting in 48 pieces, which were distributed randomly to the eight treatments. In all treatments the ovarian pieces were cut in the tissue chopper from the cortical to medullar side. The ovarian fragments obtained were then placed in $50 \mathrm{ml}$ of PBS (Phosphate Buffered Saline) plus 5\% goat serum (Sigma), suspended 40 times with a large Pasteur pipette (diameter-1600 $\mu \mathrm{m}$ ) and 40 times with a smaller Pasteur pipette (diameter $-600 \mu \mathrm{m}$ ). The suspensions were filtered successively through 500 and $100 \mu \mathrm{m}$ nylon mesh filters (Fig. 1). Each treatment was repeated seven times. 


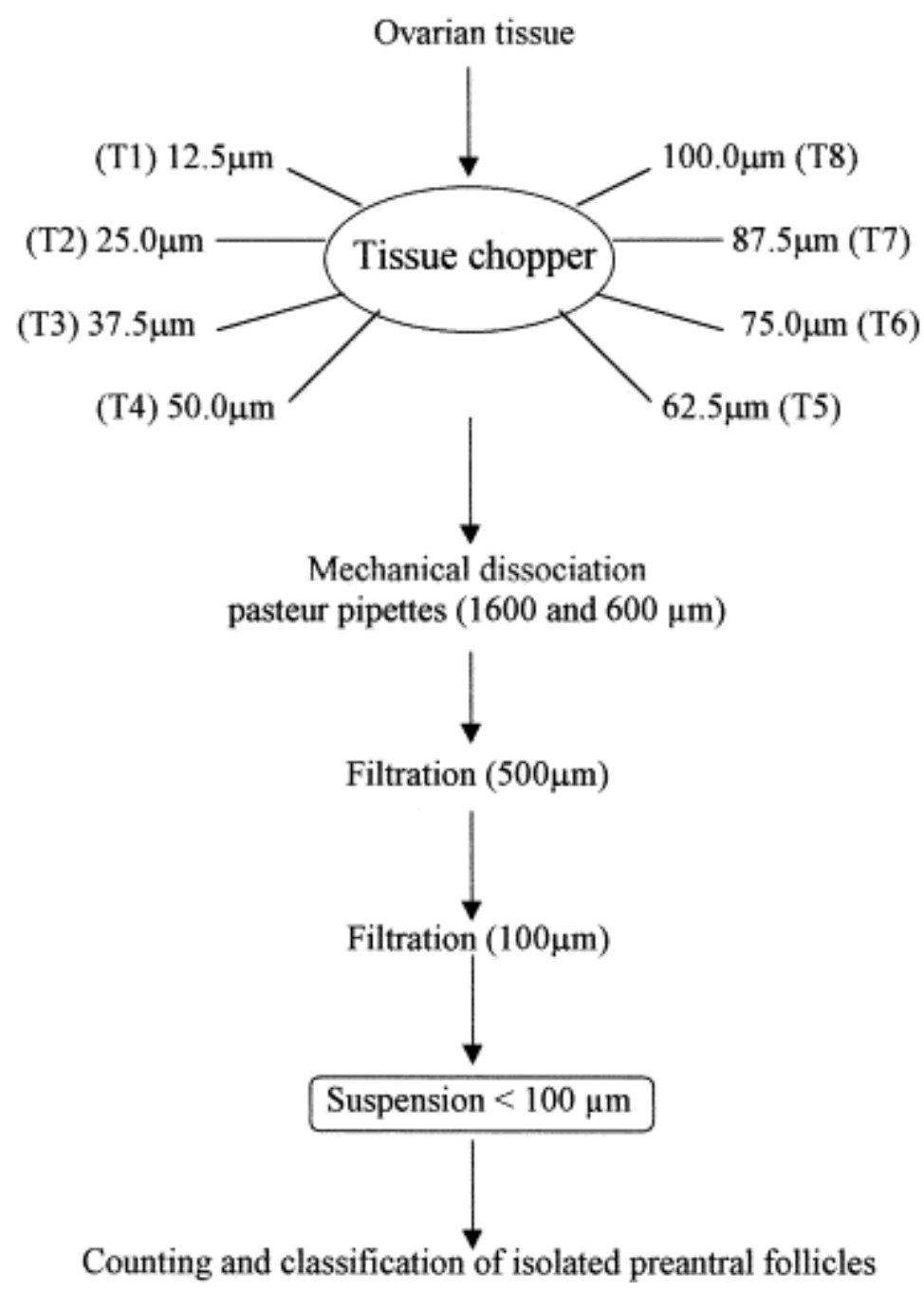

Fig. 1. Experimental protocol to isolate preantral follicles from caprine ovaries.

To estimate the number of isolated preantral follicles per treatment, the suspension $<100 \mu \mathrm{m}$ was homogenized and then, two samples of $1 \mathrm{ml}$ each were taken and examined separately at the inverted microscope (Zeiss). The follicular diameters were measured with an ocular micrometer, considering the smaller diameter.

The isolated preantral follicles were classified by their morphological appearance according to Hulshof et al. (1994), i.e. primordial follicles are oocytes surrounded by one layer of squamous or squamous-cuboidal granulosa cells; primary follicles have a single layer of cuboidal granulosa cells, and secondary follicles are oocytes surrounded by two or more layers of cuboidal granulosa cells. 


\subsection{Qualitative analysis of isolated preantral follicles}

To evaluate the quality of the isolated preantral follicles, variables such as integrity of the basement membrane, cellular density, presence or absence of picnotic bodies and integrity of the oocyte were observed. Follicular quality was evaluated only in the treatment that yielded the largest number of isolated preantral follicles.

\subsubsection{Histology}

Freshly isolated preantral follicles were briefly fixed in a solution containing $2 \%$ paraformaldehyde and $2.5 \%$ glutaraldehyde in $0.1 \mathrm{M}$ cacodylate buffer, $\mathrm{pH} 7.2$, for $30 \mathrm{~min}$ at room temperature. Subsequently, the follicles were embedded in drops of $200 \mu \mathrm{l}$ of $4 \%$ agar solution (agarose, type VII, Sigma, St. Louis, MO, USA). The agar drops were fixed again in the same fixation solution described above for $3 \mathrm{~h}$ at room temperature. After the fixation procedure, they were dehydrated in a graded series of ethanol, clarified with xylol, and embedded in paraffin wax. Sections of $7 \mu \mathrm{m}$ were stained with periodic acid schiff (PAS) and haematoxylin.

\subsubsection{Transmission electron microscopy}

Some isolated follicles were embedded in agar drops and fixed as described above. After washing with sodium cacodylate buffer, postfixation in a solution containing $1 \%$ osmium tetroxide, $0.8 \%$ potassium ferricyanide and $5 \mathrm{mM}$ calcium chloride in $0.1 \mathrm{M}$ cacodylate buffer was performed. Subsequently, the samples were dehydrated in acetone and embedded in Spurr. Thin sections $(70 \mathrm{~nm})$ were stained with uranyl acetate and lead citrate, and examined in a Jeol JEM 100 C transmission electron microscope.

\subsection{Statistical Analysis}

To compare the numbers of isolated preantral follicles among treatments, data were subjected to log transformation and ANOVA. Differences among individual means were tested using Duncan's Multiple Range test (SAS). Values were considered statistically significant when $p<0.05$. 


\section{Results}

\subsection{Isolation of ovarian preantral follicles}

Data regarding the effect of eight different intervals of serial sections in the tissue chopper on the number of isolated preantral follicles per ovary are included in Table 1 . The mechanical treatment of goat ovaries provides a large number of isolated preantral follicles, irrespective of the interval used for serial sectioning. However, a large individual variation in the number of isolated follicles within the treatments was observed. The limits of this variation were 1550 (T8) and 17220 (T5) preantral follicles per ovary. The mean number of isolated preantral follicles per ovary increased from T1 $(12.5 \mu \mathrm{m})$ to T6 $(75.0 \mu \mathrm{m})$ and decreased afterwards in T7 $(87.5 \mu \mathrm{m})$ and T8 $(100.0 \mu \mathrm{m})$. However, only T6 $(75.0 \mu \mathrm{m})$ showed a significantly higher number of isolated preantral follicles compared with T1 $(12.5 \mu \mathrm{m})$ and T8 $(100.0 \mu \mathrm{m})$. Significantly more follicles were isolated in T5 $(62.5 \mu \mathrm{m})$ when compared with T8 $(100.0 \mu \mathrm{m})$.

Table 1 Number of isolated ovarian preantral follicles (mean \pm SEM) at eight different sections interval

\begin{tabular}{lll}
\hline Treatment $($ section interval) & \multicolumn{2}{l}{ Number of follicles per ovary $(n=84)$} \\
\cline { 2 - 3 } & Mean \pm SEM & Range \\
\hline T1 $(12.5 \mu \mathrm{m})$ & $4937 \pm 1025^{2, c}$ & $1625-7887$ \\
T2 $(25.0 \mu \mathrm{m})$ & $6441 \pm 1932^{2, \mathrm{~b}, \mathrm{c}}$ & $1637-13813$ \\
$\mathrm{~T} 3(37.5 \mu \mathrm{m})$ & $8052 \pm 1896^{\mathrm{a}, \mathrm{b}, \mathrm{e}}$ & $2375-15575$ \\
$\mathrm{~T} 4(50.0 \mu \mathrm{m})$ & $6971 \pm 1278^{\mathrm{a}, \mathrm{b}, \mathrm{c}}$ & $2725-10975$ \\
T5 $(62.5 \mu \mathrm{m})$ & $8589 \pm 1653^{2, \mathrm{~b}}$ & $2875-17220$ \\
T6 $(75.0 \mu \mathrm{m})$ & $9664 \pm 1577^{\mathrm{b}}$ & $5650-16975$ \\
T7 $(87.5 \mu \mathrm{m})$ & $4957 \pm 684^{\mathrm{ab}, \mathrm{c}}$ & $2625-7175$ \\
T8 $(100.0 \mu \mathrm{m})$ & $3542 \pm 540^{\mathrm{c}}$ & $1550-4625$ \\
\hline$a, \mathrm{~b}, \mathrm{c}(p<0.05)$. & &
\end{tabular}

\subsection{Morphology and distribution of freshly isolated preantral follicles}

The suspension $(<100 \mu \mathrm{m})$ obtained after mechanical treatment of the ovaries contained numerous isolated preantral follicles, ovarian stroma cells and large tissue parts. The isolated follicles varied in size and appearance (Fig. 2). Primordial follicles were characterized by an oocyte surrounded by one layer of flattened granulosa cells. In primary follicles, only a small part of the oocyte was visible; the remainder was covered by one layer of cuboidal granulosa cells. Secondary follicles had more than one layer of cuboidal granulosa cells. The oocyte was not always clearly visible because it was covered by granulosa cells.

Isolated primordial, primary and secondary follicles had a mean ( \pm SD) diameter of $21.5 \pm 3.7,34.7 \pm 6.1$ and $65.3 \pm 22.3 \mu \mathrm{m}$, respectively. Taking the treatments together, the 
population of isolated preantral follicles was composed of $96.3 \%$ primordial, $2.5 \%$ primary and $1.2 \%$ secondary follicles.

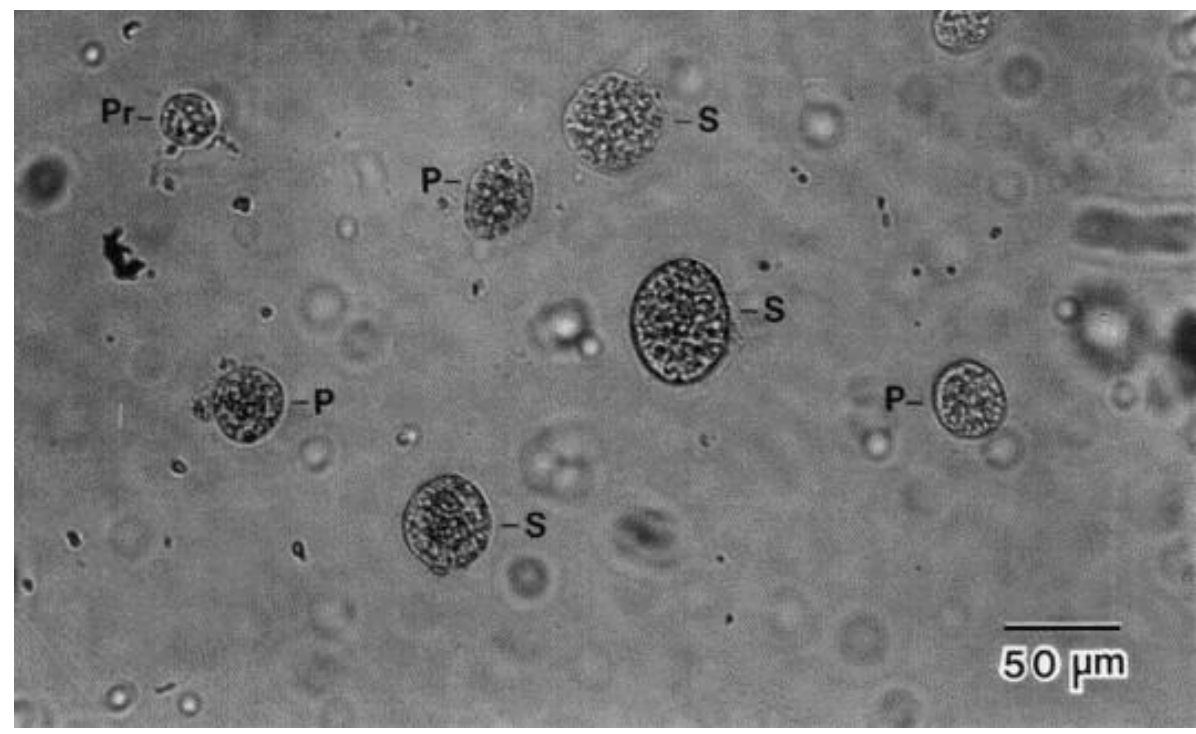

Fig. 2. Fresh, mechanically-isolated caprine preantral follicles. Pr: primordial follicle; P: primary follicle; S: secondary follicle.

\subsection{Qualitative analysis of isolated preantral follicles}

In addition to the greater number of preantral follicles isolated, the T6 $(75.0 \mu \mathrm{m})$ allowed the preservation of follicular integrity. Freshly isolated preantral follicles appeared healthy under the inverted microscope. They were spherical, with one or more organized layers of granulosa cells around the oocyte, surrounded by a basement membrane and with no antrum. No denuded oocytes were observed in this study.

Histological evaluation shows that after mechanical isolation $93 \%$ of preantral follicles were morphologically normal with a healthy oocyte surrounded by one or more well organized layers of granulosa cells without pycnotic nuclei (Fig. 3a). Histochemistry, using periodic acid schiff (PAS), also revealed that the mechanically isolated follicles were surrounded by an intact basement membrane.

The percentage of degenerated follicles was very low (7\%) and the degeneration was observed mainly in the oocyte. In degenerated follicles, the oocyte was contracted and strongly stained with PAS and its nuclear chromatin was also clumped (Fig. 3b). The granulosa cells were apparently unaffected. The signs of atresia were not identified with the inverted microscope, but were detected only by histology. 
Ultrastructural analysis of isolated follicles showed that the basement membrane is composed of a compact lamina in the inner part surrounded by a thick layer of collagen fibers (Fig. 4a). The integrity of the oocyte and granulosa cells was confirmed (Fig. 4b).
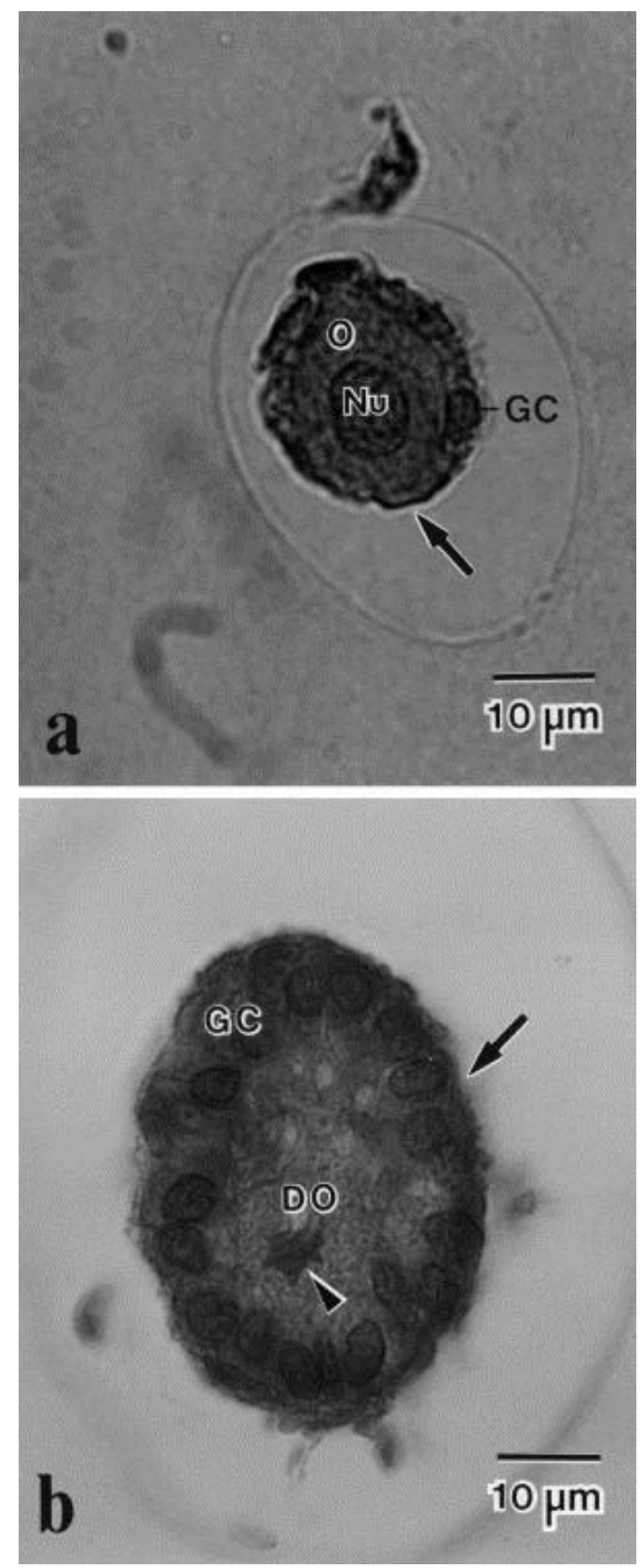

Fig. 3. Histological section of (a) a morphologically normal follicle and (b) a degenerated follicle after mechanical isolation. O: Normal oocyte; Nu: Nucleus of a normal oocyte; GC: Granulosa cells; DO: Degenerating oocyte (arrow-head marks condensed nucleus). The basement membrane surrounding the follicles is marked by arrow. 


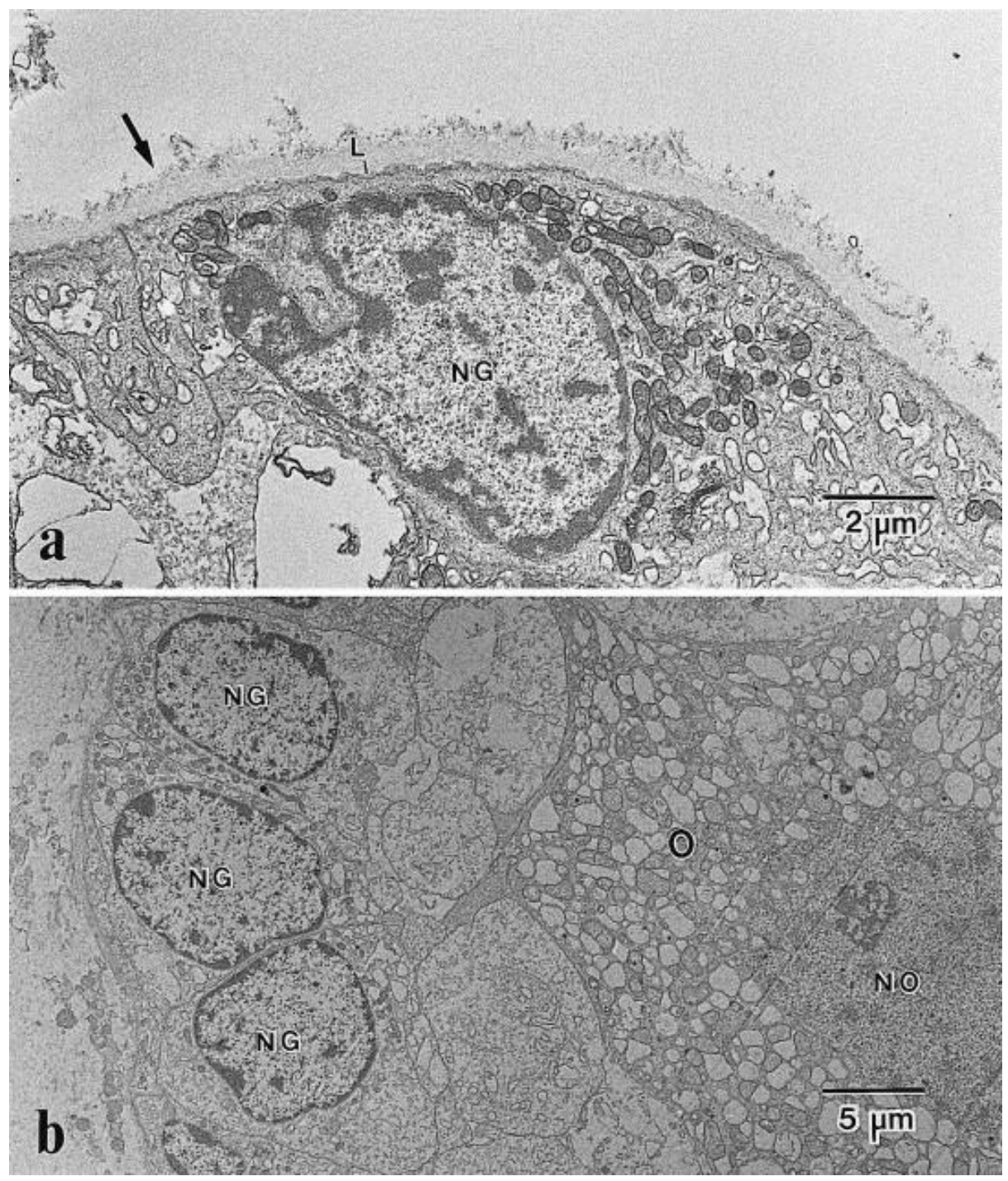

Fig. 4. Electron micrographs of preantral follicles after mechanical isolation showing (a) the basement membrane (arrow); L: Basal lamina, and (b) a normal follicle. O: Oocyte; NO: Nucleus of oocyte; NG: Nucleus of granulosa cell.

\section{Discussion}

The results of this study have shown that a large number of goat preantral follicles can be isolated using a simple mechanical procedure. Other mechanical procedures for the isolation of preantral follicles are described in the literature. Some authors isolated a large number of ovarian preantral follicles from cows (Figueiredo et al., 1993; Nuttinck et al., 1993; Hulshof et al., 1994), ewes (Amorim et al., 1998), domestic cats (Jewgenow and Pitra, 1993; Jewgenow and Göritz, 1995) and non-domestic felids (Jewgenow and Stolte, 1996; Jewgenow et al., 1997). In addition, enzymatic procedures for the isolation of follicles have been used in various mammalian species (Nicosia et al., 1975; Eppig and Downs, 1987; Daniel et al., 1989; Lazzari et al., 1992; Roy and Treacy, 1993). Comparisons of our results with those of other 
authors are difficult to perform due to species differences, variation in follicle classification, and types of follicles included in the final count.

Using the tissue chopper, Figueiredo et al. (1993)developed a simple mechanical method for isolating preantral follicles from bovine ovaries. This method consists in cutting the ovarian tissue in the tissue chopper adjusted to a $50.0 \mu \mathrm{m}$ interval of serial sections. Using the same method, Rodrigues et al. (1998)isolated 1067 preantral follicles per goat ovary. The results of our research indicate that the method developed for cattle is not optimal for goats, since more follicles can be isolated from the goat ovary using a $75.0 \mu \mathrm{m}$ interval instead of a $50.0 \mu \mathrm{m}$ interval. The results of the present study demonstrated that the number of isolated preantral follicles is affected by the interval of serial sections. Similar results were described by Amorim et al. (1998). These authors related that the interval of $87.5 \mu \mathrm{m}$ is the best to isolate ovine preantral follicles. In the present study, it seems that the use of cut intervals smaller than $75.0 \mu \mathrm{m}$ may destroy preantral follicles, while the largest intervals may reduce the efficiency of mechanical dissociation of the ovarian fragments with Pasteur pipettes and thus prevent preantral follicle release from the ovarian tissue.

Great individual variation in the number of isolated follicles per ovary was observed in all intervals of serial sections tested in this study. These data are in accordance with many other authors (Jewgenow and Göritz, 1995; Jewgenow and Stolte, 1996; Amorim et al., 1998; Rodrigues et al., 1998). A variety of factors has been described which may affect ovarian follicular populations, including age (Peters, 1976), breed (Cahill et al., 1979; Driancourt et al., 1985), reproductive stage (Erickson et al., 1976), nutrition (Scaramuzzi et al., 1993) and genetic factors (Erickson, 1966aErickson, 1966b; Cahill et al., 1979).

In the present study, no denuded oocytes were observed, probably because the basement membrane offers mechanical resistance and presumably protects the follicles from physical damage during isolation, as suggested by Figueiredo et al. (1995). Histochemical and ultrastructural analysis demonstrated that mechanically isolated goat preantral follicles are surrounded by an intact basement membrane. Similar results were obtained by Figueiredo et al., 1994 and Figueiredo et al., 1995and Amorim et al. (1998)using the tissue chopper to isolate bovine and ovine preantral follicles, respectively. In contrast, some studies have pointed out that proteolytic enzymes commonly used for isolating follicles are detrimental to cell membranes (Cavanaugh et al., 1963; Grob, 1964; Kono, 1969; Post, 1971; Nicosia et al., 1975). In vitro culture of enzymatically isolated preantral follicles, which are not surrounded by a basal lamina, shows a spreading of granulosa cells from the oocytes (Maresh et al., 1990; Eppig, 1992). In contrast, this latter alteration was not observed when mechanically isolated preantral follicles were cultured in vitro (Figueiredo et al., 1994). The culture of preantral 
follicles surrounded by a natural basement membrane has many advantages including preservation of follicular morphology and maintenance of follicular adhesion to extracellular compounds (Figueiredo et al., 1994). Thus, the presence of a basement membrane around the isolated follicles is important for further studies of in vitro culture of goat preantral follicles.

The percentage of primordial follicles was greater than for primary and secondary follicles in all cut intervals tested. Similar proportions were reported in histological studies in ovine (Driancourt et al., 1985) and bovine ovaries (Erickson, 1966b). Rodrigues et al. (1998)and Amorim et al. (unpublished results) also showed similar results in the isolation of caprine and ovine preantral follicles, respectively. However, Hulshof et al. (1994)isolated a greater percentage of primary (57.2\%) than primordial follicles (12.4\%) from bovine fetal ovaries. These authors suggest that the lesser percentage of isolated primordial follicles may be due to these follicles being tightly embedded in the tunica albuginea, whereby a mild mechanical treatment is not sufficient to isolate primordial follicles.

The diameters of isolated primordial, primary and secondary follicles were similar to the diameters reported for caprine (Rodrigues et al., 1998) and ovine (Amorim et al., unpublished results) preantral follicles, but were smaller than those reported for preantral follicles from bovine fetuses (Hulshof et al., 1994). The smaller diameter of the caprine preantral follicles may be due to species differences.

In conclusion, this work provides evidence that the number of isolated goat preantral follicles is affected by the interval of serial sections of ovarian tissue in the tissue chopper. The most desirable interval is $75.0 \mu \mathrm{m}$ because it yielded the largest number of intact preantral follicles from adult goat ovaries. In the future, the recovery and culture of a large number of preantral follicles will be essential to provide viable oocytes for in vitro maturation and fertilization techniques, for multiplying valuable or endangered animals.

\section{Acknowledgements}

This study was supported by the Laboratório de Morfologia e Morfogênese and the Laboratório de Microscopia Eletrônica of University of Brasília, Brazil and University of Liège, Belgium. The authors thank Antônio Djalma Santos for technical assistance and Zélia Ramos Madeira for the English correction of the manuscript. 
References

Amorim, C.A., Rodrigues, A.P.R., Lucci, C.M., Figueiredo, J.R., Goncçalves, P.B.D., 1998. Mechanical method for the isolation of preantral follicles from adult ovine ovaries. Arq. Fac. Vet. UFRGS, Porto Alegre 261 , 215, Suppl.

Cahill, L.P., Mariana, J.C., Mauleon, P., 1979. Total follicular populations in ewes of high and low ovulation rates. J. Reprod. Fertil. 55, 27-36.

Carroll, J., Whittingham, D.G., Wood, M.J., Telfer, E., Gosden, R.G., 1990. Extra-ovarian production of mature viable mouse oocytes from frozen primary follicles. J. Reprod. Fertil. 90, 321-327.

Cavanaugh, D.J., Berndt, W.O., Smith, T.E., 1963. Dissociation of heart cells by collagenase. Nature 200, 261-262.

Daniel, S.A.J., Armstrong, D.T., Gore-Langton, R.E., 1989. Growth and development of rat oocytes in vitro. Gamete Res. 24, 109-121.

Driancourt, M.A., Cahill, L.P., Bindon, B.M., 1985. Ovarian follicular populations and preovulatory enlargement in booroola and control merino ewes. J. Reprod. Fertil. 73, 93-107.

Eppig, J.J., 1992. Growth and development of mammalian oocytes in vitro. Arch. Pathol. Lab. Med. 116, 379-382.

Eppig, J.J., Downs, S.M., 1987. The effect of hypoxanthine on mouse oocyte growth and development in vitro: maintenance of meiotic arrest and gonadotropin-induced oocyte maturation. Dev. Biol. 119, 313-321.

Erickson, B.H., 1966a. Development and radio-response of the prenatal bovine ovary. J. Reprod. Fertil. 10, 97-105.

Erickson, B.H., 1966b. Development and senescence of the postnatal bovine ovary. J. Anim. Sci. 25, 800-805. Erickson, B.H., Reynolds, R.A., Murphree, R.L., 1976. Ovarian characteristics and reproductive performance of the aged cow. Biol. Reprod. 15, 555-560.

Figueiredo, J.R., Hulshof, S.C.J., Van Den Hurk, R., Ectors, F.J., Fontes, R.S., Nusgens, B., Bevers, M.M., Beckers, J.F., 1993. Development of a combined new mechanical and enzymatic method for the isolation of intact preantral follicles from fetal, calf and adult bovine ovaries. Theriogenology 40, 789-799.

Figueiredo, J.R., Hulshof, S.C.J., Van Den Hurk, R., Nusgens, B., Bevers, M.M., Ectors, F.J., Beckers, J.F.,1994. Preservation of oocyte and granulosa cell morphology in bovine preantral follicles cultured in vitro. Theriogenology 41, 1333-1346.

Figueiredo, J.R., Hulshof, S.C.J., Thiry, M., Van Den Hurk, R., Bevers, M.M., Nusgens, B., Beckers, J.F., 1995. Extracellular matrix proteins and basement membrane: their identification in bovine ovaries and significance for the attachment of cultured preantral follicles. Theriogenology 43, 845-858. 
Greenwald, G.S., Moor, R.M., 1989. Isolation and preliminary characterization of pig primordial follicles. J.Reprod. Fertil. 87, 561-571.

Grob, H.S., 1964. Enzymatic dissection of the mammalian ovary. Science 146, 73-74.

Hulshof, S.C.J., Figueiredo, J.R., Beckers, J.F., Bevers, M.M., Van Den Hurk, R., 1994. Isolation and characterization of preantral follicles from foetal bovine ovaries. The Veterinary Quarterly $16,78-80$.

Jewgenow, K., Goritz, F., 1995. The recovery of preantral follicles from ovaries of domestic cats and their characterization before and after culture. Anim. Reprod. Sci. 39, 285-297.

Jewgenow, K., Pitra, C., 1993. Hormone-controlled culture of secondary follicles of domestic cats. Theriogenology 39, 527-535.

Jewgenow, K., Stolte, M., 1996. Isolation of preantral follicles from nondomestic cats-viability and ultrastructural investigations. Anim. Reprod. Sci. 44, 183-193.

Jewgenow, K., Blottner, S., Lengwinat, T., Meyer, H.H.D., 1997. New methods for gamete rescue from gonads of non domestic felids. J. Reprod. Fertil. 51, 33-39, Suppl.

Kono, T., 1969. Destruction of insulin effector system of adipose tissue cells by proteolytic enzymes. J. Biol. Chem. 244, 1772-1778.

Lazzari, G., Galli, C., Moor, R.M., 1992. Centrifugal elutriation of porcine oocytes isolated from the ovaries of newborn piglets. Anal. Biochem. 200, 31-35.

Maresh, G.A., Timmons, T.M., Dunbar, B.S., 1990. Effects of extracellular matrix on the expression on specific ovarian proteins. Biol. Reprod. 43, 965-976.

Nicosia, S.V., Evangelista, I., Batta, S.K., 1975. Rabbit ovarian follicles. I. isolation technique and characterization at different stages of development. Biol. Reprod. 13, 423-447.

Nuttinck, F., Mermillod, P., Massip, A., Dessy, F., 1993. Characterization of in vitro growth of bovine preantral ovarian follicles: a preliminary study. Theriogenology 39, 811-821.

Peters, H., 1976. The development and maturation of the ovary. Ann. Biol. Anim. Bioch. Biophys. 16, 271-278.

Post, G., 1971. Adsorption and activity of enzymes at the cell surface. tissue dissociation with proteolytic enzymes. Exp. Cell Res. 65, 359-367.

Rodrigues, A.P.R., Amorim, C.A., Lucci, C.M., Figueiredo, J.R., Gonc, alves, P.B.D., Bem, A.R. 1998. Isolamento mecanico de folıculos ovarianos pre-antrais em cabras. Ciencia Rural, 28 , in press.

Roy, S.K., Treacy, B.J., 1993. Isolation and long-term culture of human preantral follicles. Fertil. Steril. 59, 783-790.

Saumande, J., 1991. La folliculogenese chez les ruminants. Rec. Med. Vet. 167, 205-218. 
Scaramuzzi, R.J., Adams, N.R., Baird, D.T., Campbell, B.K., Downing, J.A., Findlay, J.K., Henderson, K.M., Martin, G.B., Mcnatty, K.P., Mcneilly, A.S., Tsonis, C.G., 1993. A model for follicle selection and the determination of ovulation rate in the ewe. Reprod. Fertil. Dev. 5, 459-478 